\title{
Introducing design-driven innovation into Brazilian MSMEs: Barriers and next challenges of design support
}

\author{
FONSECA BRAGA Mariana ${ }^{\mathrm{ab}^{*}}$; ZURLO Francesco ${ }^{\mathrm{a}}$ \\ ${ }^{a}$ Department of Design, Politecnico di Milano \\ ${ }^{\mathrm{b}}$ National Council for Scientific and Technological Development (CNPq, Brazil) \\ * Corresponding author e-mail: mfbraga@gmail.com \\ doi: 10.21606/dma.2018.442
}

\begin{abstract}
What are the barriers to introducing design-driven innovation into micro, small and medium sized enterprises (MSMEs) in mature industries through design support? What are the next challenges? This paper aims at answering these issues, proposing recommendations to overcome the barriers and exploring what is next. The research strategy was based on the analysis of two exploratory cases of design support in Brazil, taking the key stakeholders' perspectives into account. The approach is qualitative and inductive; we analyse empirical evidence using a literature review on barriers to design-driven innovation. New constraints in the inquired contexts and the ones which were found in other studies are identified and framed at three levels: individual (actors), organisational (micro), and ecosystem. Challenges are pointed out applying the HMW framework to the most promising scenario (which considered critical variables) to design-driven innovation in Brazilian MSMEs. In addition, recommendations on more immediate constraints are suggested.
\end{abstract}

Design-driven innovation; MSMEs; barriers; design support challenges

\section{Introduction}

This paper focuses on the Brazilian context, but the problematic which is addressed can be considered of global concern, being a relevant issue in emerging and mature economies (see for instance Arquilla, Maffei, Mortati, Villari, 2015; Raulik-Murphy, 2010; Schneider, Gibet, Colomb, Orazem, Loesch, Kasparyan, Salminen, 2015). MSMEs are important sources of employment and contribute to decreasing the impact of an economic crisis (Airaksinen, Luomaranta, Alajääskö \& Roodhuijzen, 2015; Bell, 2015; Cawood, 1997; Madeuf \& Estimé, 2000; Organisation for Economic Co-operation and Development [OECD], 2016, Raulik-Murphy \& Cawood, 2009). The need for innovation ranging from businesses to regions and nations has been fully recognised (OECD, 2014, ECLAC, 2015, European Comission, 2015, Galinari, Teixeira Junior, \& Morgado, 2013; Raulik-Murphy, 2010; Schnaider et al., 2014; Silveira da Rosa, Correa, Lemos, \& Barroso, 2007). Design as a way that

1. This work is licensed under a Creative Commons Attribution-NonCommercial-Share Alike 4.0 International License.

2. https://creativecommons.org/licenses/by-nc-sa/4.0/ 
leads innovation and humanizes technologies, keeping people at the core throughout its process, constitutes one path to promote change at diverse levels: from micro (organizations, businesses) to macro (policies, territories, industries, nations, ecosystems). The designer "... is concerned with how things ought to be in order to attain goals, and to function" (Simon, 1996, p. 4), this definition is still appropriate nowadays with the expansion of the design field.

\subsection{Methodology}

This research uses an inductive reasoning, starting from empirical cases to identify the integration of design's problematic in the context of design support ${ }^{1}$ when beneficiaries generally are MSMEs and have little or no design experience.

Two research strategies were combined: case study (Eisenhardt, 1989; Stake, 2000; Yin, 1994) and grounded theory (Glaser and Strauss, 1967). The case study is indicated when a contemporary phenomenon is inquired in a real context where the boundaries between the context and the phenomenon are not clearly defined (Yin, 1994). It allows diverse research phases interaction throughout the research process, which enables a better update of the research design according to the discoveries about the phenomenon and the needs found out throughout the research process (Eisenhardt, 1989). The grounded theory approach enables to evidence the meanings from empirical data (Glaser and Strauss, 1967).

Methods' triangulation was used, including semi-structured interviews (addressed to key stakeholders' representatives who take part in the design policy-making processes and implementation such as policy makers, advocates, designers and other consultants, and beneficiaries), in-depth interviews (to get insights on specific topics emerged from the semistructured interviews), desk research (data collection and analysis from brochures, projects' documents, websites of projects, institutions and companies).

The design support cases inquired were selected in collaboration with a non-profit private entity which aims at promoting the sustainable and competitive development of the Brazilian small businesses. Polar types (Eisenhardt, 1989; Glaser and Strauss, 1967) were considered in order to favour theory extension and to contribute to fill in theoretical gaps. One project in a design-intensive industry ${ }^{2}$ and another in a non-design intensive industry were selected. Table 1 shows the projects' characteristics.

Table 1 Projects' characteristics.

\begin{tabular}{|c|c|c|c|}
\hline Project and context & Description & Activities & Purposes and Funding \\
\hline $\begin{array}{l}\text { P1 } \\
\text { Canastra region } \\
800 \text { cheese producers } \\
40 \text { certified } \\
\text { (Marzano, 2015) } \\
\text { Cheese from Canastra } \\
200 \text { y. tradition } \\
\text { Made of raw milk }\end{array}$ & $\begin{array}{l}\text { Industry: food and } \\
\text { agriculture } \\
\text { Location: Serra da Canastra } \\
\text { (Minas Gerais Federation, } \\
\text { Brazil) } \\
\text { MSMEs (beneficiaries): } \\
\text { This design support initiative } \\
\text { counted on } 30 \text { to } 45 \\
\text { beneficiaries from } 2013 \text { to }\end{array}$ & $\begin{array}{l}\text { Cultural heritage } \\
\text { identification and } \\
\text { registration (verbal } \\
\text { language, community } \\
\text { behaviour, territory } \\
\text { features, institutional } \\
\text { videos) } \\
\text { Brand, tags and package } \\
\text { design (for a consortium of } \\
6 \text { businesses that shared }\end{array}$ & $\begin{array}{l}\text { To develop the territorial } \\
\text { brand as well as } \\
\text { individual producers } \\
\text { brands. } \\
\text { To support making } \\
\text { products suitable for } \\
\text { quality and compulsory } \\
\text { certifications regulations, } \\
\text { promoting a better } \\
\text { communication of }\end{array}$ \\
\hline
\end{tabular}

\footnotetext{
1 “Design support programmes are a policy instrument for improving the use of design and can comprise of one-to-one mentoring ranging from light-touch to more specialised interventions as well as subsidies, tax credits and export schemes." (Whicher, Swiatek, Cawood, p. 14, 2015) In the Brazilian case, design support is defined, developed and managed mainly by non-profit private entities. These entities are funded through a Brazilian Government's tax paid by formal companies (private firms).

2 Industries in which design plays an essential role to develop outstanding products and services, considering the definition used by Verganti (2003, p. 35) who includes furniture, lighting, kitchenware, small appliance as examples of this typology of industry.
} 


\begin{tabular}{|c|c|c|c|}
\hline Project and context & Description & Activities & Purposes and Funding \\
\hline $\begin{array}{l}2008 \text { - Productive practices } \\
\text { were considered as part of the } \\
\text { Brazilian cultural and } \\
\text { immaterial heritage by the } \\
\text { Instituto do Patrimônio } \\
\text { Histórico e Artístico Nacional } \\
\text { (IPHAN) } \\
2015 \text { - 2nd ranking } \\
\text { Mondial du Fromage et des } \\
\text { Produits Laitières (Tours, } \\
\text { France) }\end{array}$ & $\begin{array}{l}\text { 2016. This inquiry focused } \\
\text { on } 19 \text { beneficiaries of design } \\
\text { interventions that included a } \\
\text { major range of activities } \\
\text { proposed. } \\
\text { Projects studied were } \\
\text { carried out from } 2013 \text { to } \\
2016\end{array}$ & $\begin{array}{l}\text { the same brand, and for } \\
\text { other individual } \\
\text { businesses). } \\
\text { Research of best practices } \\
\text { in loco. }\end{array}$ & $\begin{array}{l}\text { product origin and } \\
\text { values. } \\
\text { The non-profit entity } \\
\text { funds from } 60 \% \text { to } 80 \% \text { of } \\
\text { the design interventions, } \\
\text { and the beneficiaries pay } \\
\text { (refund the institution) } \\
\text { from } 40 \% \text { to } 20 \% \text { of the } \\
\text { total economic value. }\end{array}$ \\
\hline $\begin{array}{l}\text { P2 } \\
3^{\text {rd }} \text { Brazilian Lingerie Cluster } \\
160 \text { manufacturers } \\
\text { Focus on wholesale B2B } \\
\text { (Guedes, 2014) }\end{array}$ & $\begin{array}{l}\text { Industry: fashion } \\
\text { Location: Juruaia } \\
\text { (Minas Gerais Federation, } \\
\text { Brazil) } \\
\text { MSMEs (beneficiaries): } \\
\text { This project started with } 25 \\
\text { beneficiaries but } 15 \text { left the } \\
\text { project before its conclusion } \\
\text { because of the own (from } \\
\text { the entrepreneurs) } \\
\text { investment required to open } \\
\text { their store. } \\
\text { Projects studied were } \\
\text { carried out from } 2010 \text { to } \\
2014\end{array}$ & $\begin{array}{l}\text { Technical drawing lingerie } \\
\text { modeling workshop. } \\
\text { Research of best practices } \\
\text { in loco. } \\
\text { Mentoring, coaching. } \\
\text { Development of brand } \\
\text { identities, tags, packages } \\
\text { design, and other } \\
\text { communication materials. } \\
\text { Store design for the } \\
\text { consortium of firms (same } \\
\text { store and brand shared by } \\
\text { a group of entrepreneurs). } \\
\text { Lingerie collection design }\end{array}$ & $\begin{array}{l}\text { To enlarge the } \\
\text { beneficiaries market } \\
\text { share introducing the } \\
\text { products into the B2C } \\
\text { market through a new } \\
\text { retail store, to improve } \\
\text { the quality and update } \\
\text { the industry trends. } \\
\text { The non-profit entity } \\
\text { funds from } 70 \% \text { to } 80 \% \text { of } \\
\text { the design interventions, } \\
\text { and the beneficiaries pay } \\
\text { (refund the institution) } \\
\text { from } 30 \% \text { to } 20 \% \text { of the } \\
\text { total economic value. }\end{array}$ \\
\hline
\end{tabular}

All interviews were done in the first language of the interviewee. They were recorded and transcribed. Fragments of the interviewees' speech referring to barriers, clearly connected to the research issues, were translated. Statements that appeared to have personal nature were excluded. A report including the subjects of interest for this research was elaborated and sent to the interviewees in order to validate the information.

Seven representatives of key stakeholders were interviewed (policy makers and project managers, designers and other consultants, and beneficiaries). The interviews were carried out between October 2016 and May 2017. The duration ranged from forty minutes to one hour and thirty minutes.

The analysis of the interviews proceeded in convergence with grounded theory reasoning principle of elicitation, first attributing codes to the texts fragments selected from interviews, summarizing them in short phrases or themes. Second, these themes were clustered according to the similarity between them through cross-reference. Finally, they were confronted with the existing literature enabling to distinguish between the new barriers and the ones that were already identified in prior research (Tables 3, 4, 5).

Three levels of analysis of drivers and barriers were settled as follows:

- The actors level: policy makers, designers and consultants, and beneficiaries as individuals;

- The organisational level: the micro level regarding organisational structure, culture and design process in the firm;

- The ecosystem level: the industry, economic, political and educational environment. 
The introduction or integration of design-driven innovation into MSMEs is also studied in the literature with other terminologies such as: to absorb design management capabilities, to learn to use design, to adopt design, to innovate by design, to bring design into business strategy. The main fields that deal with the issue identified in this research were: Design management, Strategic design, Product innovation, Design capabilities, Knowledge management, Design thinking, Creativity, Innovation and Organisational studies. The barriers to design-driven innovation found in the literature came from these fields at the actors and at the organisational level. In the ecosystem level, they were additionally recognised in the Industrial policy, Innovation policy, Design policy, Economics, and Finance field.

Future challenges were elaborated through the identification of critical variables in each level analysed, envisioning a preferred scenario to design-driven innovation, and by applying the 'How Might We' (HMW) question framework from design thinking approach (Ideo.org, n.d.).

\subsection{Design and MSMEs: a potential relationship towards change, innovation, productivity and economic growth}

Micro, small and medium-sized enterprises (MSMEs) are considered important sources of economic growth, job creation and social cohesion in advanced and emerging economies (Cawood, 1997; Bell, 2015; Madeuf \& Estimé, 2000; OECD, 2016, Raulik-Murphy \& Cawood, 2009).

There is not a universal definition of MSMEs. MSMEs are, generally, non-subsidiary firms and the criteria used to define MSMEs are based on the number of employees, turnover and financial assets (OECD, 2006, 2016). These numbers vary across countries (OECD, 2006, 2016) as well as the definition and rules applied to employees in each country (European Commission, 2015b). In Brazil, the Brazilian National Confederation of Industry (Confederação Nacional das Indústrias [CNI]) considers as MSMEs firms in industry sectors that have fewer than 250 employees (CNI, n.d.c). the Brazilian Micro and Small Business Support Service (Serviço Brasileiro de Apoio às Micro e Pequenas Empresas [SEBRAE]) sets the limit at 99 employees for firms in the trade and services sectors (SEBRAE, 2014). Table 2 shows the values considered according to these institutions in Brazil (CNI, n.d.c; SEBRAE, 2014, n.d.a) and according to the European Commission in Europe (European Commission, 2015b).

Table 2. MSMEs criteria adopted by diverse institutions.

\begin{tabular}{|l|l|l|l|l|l|}
\hline According to & $\begin{array}{l}\text { Enterprize } \\
\text { category }\end{array}$ & $\begin{array}{l}\text { Headcount } \\
\text { Annual Work } \\
\text { Unit (AWU) }\end{array}$ & $\begin{array}{l}\text { Annual } \\
\text { turnover }\end{array}$ & & $\begin{array}{l}\text { Annual balance } \\
\text { sheet }\end{array}$ \\
\hline \multirow{2}{*}{$\begin{array}{l}\text { European } \\
\text { Comission } \\
\text { (2015b) }\end{array}$} & Medium-sized & $<250$ & $\leq € 50$ million & or & $\leq € 43$ million \\
\cline { 2 - 7 } & Small & $<50$ & $\leq € 10$ million & or & $\leq € 10$ million \\
\cline { 2 - 7 } & Micro & $<10$ & $\leq € 2$ million & or & $\leq € 2$ million \\
\hline \multirow{2}{*}{$\begin{array}{l}\text { CNI (Brazil) } \\
\text { Industry }\end{array}$} & Medium-sized & $<250$ & - & & - \\
\cline { 2 - 7 } & Small & $<50$ & $\begin{array}{l}\leq 53.6 \text { million } \\
\text { BRL }\end{array}$ & & - \\
\cline { 2 - 7 } & Micro & $<10$ & $\begin{array}{l}\leq 360 \text { thousand } \\
\text { BRL }\end{array}$ & & - \\
\hline \multirow{2}{*}{$\begin{array}{l}\text { SEBRAE (Brazil) } \\
\text { Trade and } \\
\text { services }\end{array}$} & Medium-sized & $<100$ & - & & - \\
\cline { 2 - 7 } & Small & $<50$ & $\begin{array}{l}\leq 3.6 \text { million } \\
\text { BRL }\end{array}$ & & - \\
\hline
\end{tabular}




\begin{tabular}{|l|l|l|l|l|l|}
\hline According to & $\begin{array}{l}\text { Enterprize } \\
\text { category }\end{array}$ & $\begin{array}{l}\text { Headcount } \\
\text { Annual Work } \\
\text { Unit (AWU) }\end{array}$ & $\begin{array}{l}\text { Annual } \\
\text { turnover }\end{array}$ & $\begin{array}{l}\text { Annual balance } \\
\text { sheet }\end{array}$ \\
\hline & Micro & $<10$ & $\begin{array}{l}\leq 360 \text { thousand } \\
\text { BRL }\end{array}$ & - \\
\hline
\end{tabular}

MSMEs generate four out of five new positions of formal jobs in emerging economies (Bell, 2015). They contribute to 45 percent of formal employments and 33 percent of national income (Gross Domestic Product [GDP]) (Bell, 2015). The World Bank estimates that there are between 365-445 million micro, small and medium enterprises (MSMEs) in emerging economies: 25-30 million are formal MSMEs; 55-70 million are formal micro-enterprises; and 285-345 million are informal enterprises (Bell, 2015). 600 million jobs will be needed before 2030 to absorb the global growing workforce (Bell, 2015), which reinforces the need for innovation in MSMEs towards a more sustainable scenario for these businesses, considering their potential contribution to creating jobs.

In the European Union (EU), 99 percent of companies are MSMEs. They contributed with 57 percent of value added in 2012 (Airaksinen, Luomaranta, Alajääskö, \& Roodhuijzen, 2015). Gross value added (GVA) and employment are the two main measures that have been used to describe the MSMEs contribution to economies. The first makes economies wealthier, and the latter keeps the unemployment rate low (Airaksinen, et al, 2015).

In Brazil, 99 percent of businesses are MSEs, generating 52 percent of formal jobs (excluding the agriculture sector) in 2013 (Serviço Brasileiro de Apoio às Micro e Pequenas Empresas [SEBRAE] \& Departamento Intersindical de Estatística e Estudos Socioeconômicos [DIEESE], 2015) and contributed to 27 percent of the Brazilian GVA in 2011 (SEBRAE, 2014).

The need to reduce inequalities related to MSMEs' productivity between mature and emerging economies through innovation, education and skills deployment is pointed out in order to consolidate the economic growth in developing countries (OECD, 2014; Economic Commission for Latin America and the Caribbean [ECLAC], 2015; European Commission, 2015a).

Despite the absence of a commonly agreed design definition (see for instance Arquilla, Maffei, Mortati, \& Villari, 2015; Fonseca Braga, 2016; Swann, 2010), design as:

- a way to transform a current situation into a preferred one (Simon, 1996);

- a tool that drives innovation, competitiveness and national economic growth (European Commission, 2016; Thomson \& Koskinen, 2012);

- a way to shape creativity towards innovation (Cox, 2005);

- a lever of non-technological innovations (D'Ippolito, 2014; Thomson \& Koskinen, 2012; Verganti, 2008);

- a way to humanise technologies (Heskett, 2009);

is a potential instrument to drive change, innovation, productivity and economic growth at the micro and macro levels (from organisations to nations) as evidenced in several reports (Danish Design Centre [DDC], 2003; Design Council, 2007; Design Council, 2015; European Commission, 2016; Rae, 2013, 2014; Thomson \& Koskinen, 2012).

\subsection{A brief history and context of design in Brazil}

... we could begin to trace the history of design in Brazil before the arrival of the Portuguese. In this case, we would mention the capacity of indigenous Brazilians to objects - networks, screens, baskets and banks - in perfect harmony with nature and with an inherent artistic expression. (Borges, 2009, p. 57) 
The influence of architects, such as Oscar Niemeyer, Lucio Costa, and Sergio Rodrigues, as well as Joaquim Tenreiro's and Zanine Caldas's furniture design, marked the basis of modern design and architecture in Brazil since the 1940's (Borges, 2009). In 1964, the Industrial Design College (Escola Superior de Desenho Industrial [ESDI]) was founded in Rio de Janeiro, and held the first higher education design course in South America; the educational programme followed the Ulm School in Germany, having some professors from there (Borges, 2009; Moraes, 2006; Moraes Junior, 2002). The professors' backgrounds were in architecture and engineering (Borges, 2009).

The economic model adopted as well as the late and forced industrialization process since 1964, when the military junta took power, led to the Brazilian identity crisis (Borges, 2009, 2011; Moraes Junior, 2002). Multinational enterprises, mainly from the United States, Europe and Japan, arrived in Brazil, influencing habits, culture and society. This process is known as modern colonization (Moraes Junior, 2002). These educational, political and industrial contexts contributed to the Brazilian rupture with its cultural roots (Borges, 2009, 2011).

After the end of the dictatorship period, in the 1990's the market openness to international competitors brought consequences to the Brazilian businesses:

Foreign products proved fatal for many companies accustomed to merely copying, since there was always a time-lapse between the original and the copy. At first a number of these companies went under, but in time the survivors grew stronger by absorbing design as a component in their manufacturing strategy. (Borges, 2009, p. 58)

In 1994, the Brazilian Design Programme was the first noteworthy government initiative in the field of design policies promoted by the Ministry of Industry and Commerce (Ministério da Indústria, Comércio Exterior e Serviços [MDIC]), recognising the need for a 'Brazil Brand' and for investing in distinctive design characteristics for Brazilian products. From this time, it is noticed the emergence of Brazilian designers in the international scenario, working for renowned brands such as Motorola, Nike, Bentley, Volkswagen, GM, Disney; doing signed design for foreign companies (e.g. Sergio Rodrigues, Campana Brothers); and having excellent performance in international design awards (e.g. if- Design Awards and Red Dot Design Award) (Borges, 2009; CBD, Apex-Brasil, MDIC, 2014; Kraichete, 2015; primary data collection). In addition, Brazilian brands start emphasising original features and multinationals with branches in Brazil settled design departments in Brazil, having Brazilian designers also in charge of products development to North America, Europe, China and India (Borges, 2009).

Despite the aspects aforementioned and the diversified industrial sector, Brazilian sectors such as furniture and automotive are still inward focused, being concerned with local content and domesticmarket, and the industry is heavily protected from foreign competition (Araújo, 2016; Arnold, 2016; Bradesco, 2017; Galinari, Teixeira Junior, \& Morgado, 2013; Moraes Junior, 2002; Organisation for Economic Co-operation and Development [OECD], 2014). Moreover, productivity growth in Brazil is associated with low value added sectors such as agriculture and mining, whereas manufacturing and services correspond to $20 \%$ of the Brazilian productivity growth, concentrating over $80 \%$ of value added and employment (OECD, 2013). The potential of manufacturing and services to contribute to the productivity growth is underexplored despite the value added and employment rates related to these sectors.

Economic reviews (Araújo, 2016; Arnold, 2016) have suggested the need to open the market to international competitors in order to strengthen the national industries. However, this initiative isolated could lead many firms to go under, especially MSMEs, because of the lack of resources and skills to lead innovation, increasing the unemployment rates. Then, combined initiatives that strengthen education, innovation, design and management skills, or, a learning process to integrate the Brazilian trade into the global one and into exports, providing appropriate support and competences to face this 'openness' process, are required for current and future generations. 


\subsection{The Brazilian Design Innovation Ecosystem}

The Figure 1 uses a framework adapted from Whicher and Walters $(2014)^{3}$ to bring a picture of the Brazilian design innovation ecosystem based on

- The Diagnostic Review of Design in Brazil (Centro Brasil Design [CBD], Agência Brasileira de Promoção de Exportações e Investimentos [Apex-Brasil], Ministério da Indústria, Comércio Exterior e Serviços [MDIC], 2014) - this study is an initial effort to measure the Brazilian design capability using as the main reference the Design Staircase Model (Kootstra, 2009) and the International Design Scoreboard (Moultrie and Livesey, 2009).The difficulties related to the lack of available data are clearly evidenced, not enabling to compare Brazil to other European contexts;

- Caloête and Westin (2014) - this publication from SEBRAE lists the Brazilian institutions, programmes, courses, university laboratories, events and fairs;

- Borges (2009) and Kraichete (2015) - this research has been carried out in partnership with the Dutch Culture Centre for International Cooperation and started to map the Brazilian design scenario, its actors and initiatives related to cultural, promotion and funding assets;

- The National Institute for Educational Studies and Research "Anísio Teixeira" (Instituto Nacional de Estudos e Pesquisas Educacionais Anísio Teixeira ([INEP], 2017);

- And, information sourced at institutional websites of actors that play a relevant role in design and innovation programmes across Brazil, such as: the Brazilian Micro and Small Business Support Service (Serviço Brasileiro de Apoio às Micro e Pequenas Empresas [SEBRAE]) (SEBRAE, n.d.b), the Brazilian National Confederation of Industry (Confederação Nacional das Indústrias [CNI]) and the National Service of Industrial Training (Serviço Nacional de Aprendizagem Industrial [SENAI]) (CNI, n.d.a, n.d.b).

This scheme does not include all initiatives and entities that compose the Brazilian Design Innovation Ecosystem, but provides examples which have national relevance and sources where to find additional available data.

\footnotetext{
${ }^{3}$ This framework is the same adopted in the European context in the Design Policy Monitor (Whicher, Swiatek \& Cawood, 2015).
} 


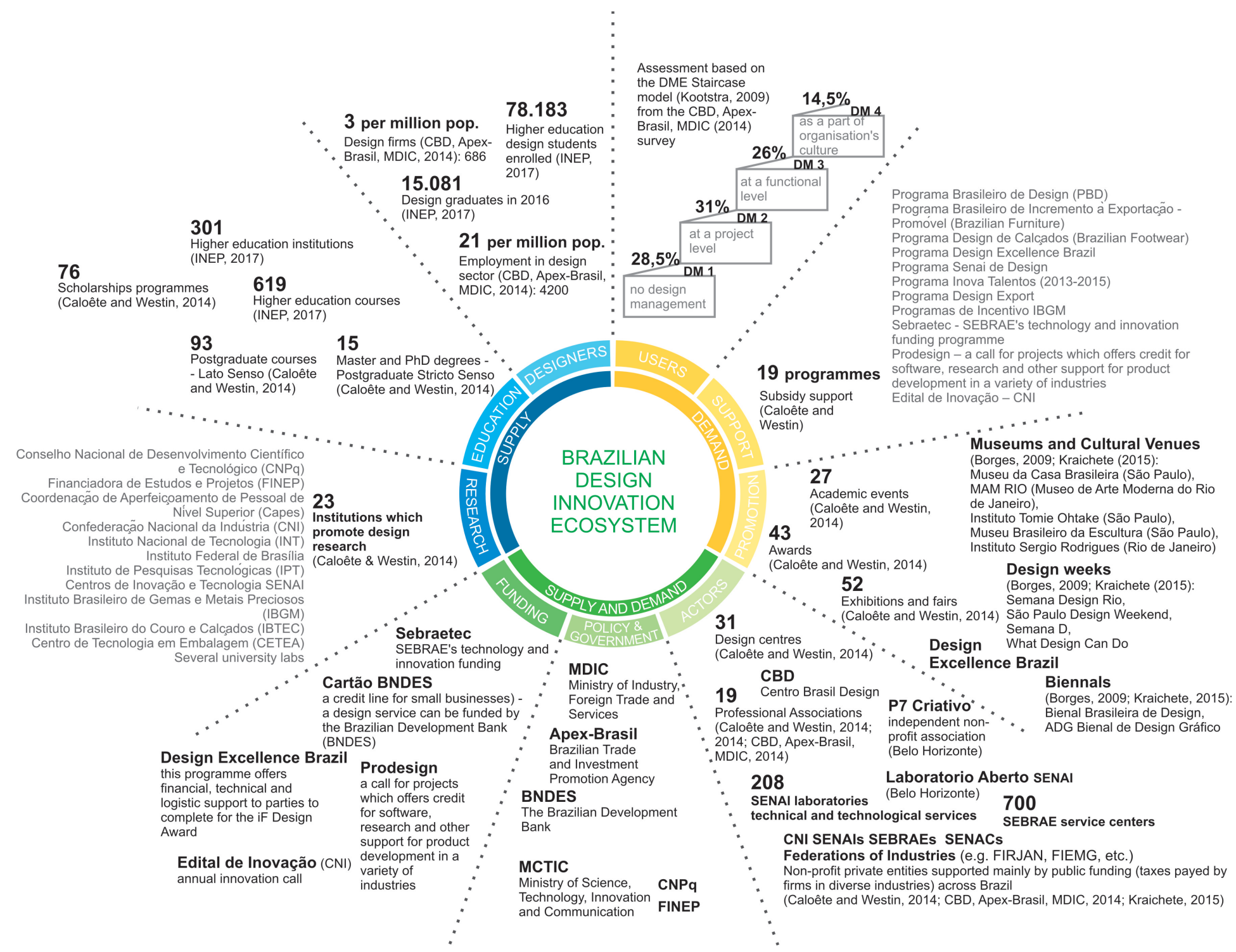

Figure 1 The Brazilian Design Innovation Ecosystem. 
The Brazilian design policies are fragmented and short-term focused (Raulik-Murphy, Cawood, Larsen, \& Lewis, 2009). Design and innovation policies publications regarding the Brazilian context have emphasised the need (a) for long run innovation strategies (Mazzucato \& Penna, 2015; RaulikMurphy, Cawood, Larsen, \& Lewis, 2009), (b) to combine diversified design policy initiatives (RaulikMurphy, 2010) and (c) to connect innovation systems that are quite fragmented across the country (Mazzucato \& Penna, 2015; Raulik-Murphy, Cawood, Larsen, \& Lewis, 2009) that is heterogeneous in terms of culture, education, innovation and design. The geography of design referred to design events (Kraichete, 2015), design jobs and firms (CBD, Apex-Brasil, MDIC, 2014) evidence these contrasting contexts across the country.

The concentration of design firms and jobs is mainly identified in the southeast and southern regions in Brazil (CBD, Apex-Brasil, MDIC, 2014). São Paulo, Rio de Janeiro, and Bento Gonçalves stand out regarding promotion initiatives. São Paulo and Rio held most design events, Bento Gonçalves held the largest furniture fair in Latin America with the Salão Design (Design Hall) Award. The first Brazilian Design Centre (Centro Brasil Design [CBD]) was founded in 1999 in Curitiba city where design concern has been evidenced also through design management studies focused on Paraná Federation companies (Murphy \& Raulik Murphy, 2015).

The design and innovation policy-making processes follow essentially a top-down approach where political influence plays a definitive role in strategies, goals and investment decisions. In contrast, experts have emphasised the importance of participatory, collaborative and bottom-up process for policy-making (Maffei, Mortati \& Villari, 2014; Whicher \& Walters, 2014).

The Diagnostic Review of Design in Brazil (CBD, Apex-Brasil, MDIC, 2014) is an initial attempt, considering that the sizes of companies that answered the survey do not represent the Brazilian reality (where 99 percent of businesses are micro and small) as well as its industry sectors. Moreover, other limitations were pointed out as follows:

... the absolute design capability indicators in Brazil are often higher in comparison with other countries. However, this can be misleading because when the numbers are placed within the national context according to the size of the population, Brazil's design resources are classified at the lowest end of the table for all indicators. It should also be considered that there is a lack of data on the indicators for public investment in design and the contribution of the design sector towards GDP. (CBD, Apex-Brasil, MDIC, 2014, p. 49)

The lack of design management studies and data on design across Latin America complicates a comparison with foreign regions (CBD, Apex-Brasil, MDIC, 2014) as well as an analysis of the state of the art of design in the country.

\section{Barriers to introducing design-driven innovation into MSMEs}

Tables 3, 4 and 5 show the barriers to design-driven innovation found in the literature review, and others spontaneously ${ }^{4}$ cited by the respondents during the interviews. These barriers were framed at three levels: actors (Table 3), organisational (Table 4), and ecosystem (Table 5). Most barriers quoted were identified in prior research, others that were highlighted were not quoted before related to design innovation in MSMEs.

\footnotetext{
${ }^{4}$ The interviewees did not have access to the barriers found in literature nor before neither during the interview.
} 
Table 3 Barriers to design-driven innovation at the actors level

\begin{tabular}{|c|c|c|c|c|}
\hline \multicolumn{2}{|c|}{ Level } & \multirow[t]{2}{*}{$R$} & \multirow{2}{*}{\begin{tabular}{|l|} 
Barrier \\
Reluctance to delegate authority or decision-making to others
\end{tabular}} & \multirow{2}{*}{$\begin{array}{l}\text { Prior research } \\
\text { Dyer and Handler (1994) } \\
\text { cited in Massa and Testa (2008) }\end{array}$} \\
\hline \multirow{17}{*}{ 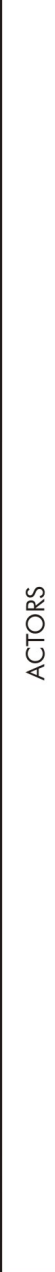 } & \multirow[t]{14}{*}{ Beneficiaries } & & & \\
\hline & & O & Over-involvement in operational-level decisions and activities & $\begin{array}{l}\text { Bruce, Cooper and Vazquez (1999) } \\
\text { Nunes (2014) } \\
\text { Raulik-Murphy and Cawood (2009) }\end{array}$ \\
\hline & & 0 & Not knowing where to turn for specialised help & $\begin{array}{l}\text { Arquilla, Maffei, Mortati and Villari (2015) } \\
\text { Cox (2005) }\end{array}$ \\
\hline & & O & Risk aversion & $\begin{array}{l}\text { Cox (2005) } \\
\text { Sternberg }(2006,2012)\end{array}$ \\
\hline & & (1) & $\begin{array}{l}\text { Passive attitude towards design with lack of cooperation / } \\
\text { engagement with designers throughout projects }\end{array}$ & Fonseca Braga (2017) \\
\hline & & & Lack of long-term strategy vision & Cawood (1997) \\
\hline & & 0 & Conventional thinking & Sternberg $(2006,2012)$ \\
\hline & & 0 & Lack of experience & $\begin{array}{l}\text { Arquilla et al. (2015) } \\
\text { Bruce et al. (1999) } \\
\text { Cox (2005) } \\
\text { Schneider, Gibet, Colomb, Orazem, } \\
\text { Loesch, Kasparyan and Salminen (2015) }\end{array}$ \\
\hline & & 0 & Lack of design awareness & $\begin{array}{l}\text { Cox (2005) } \\
\text { Filson and Lewis (2000) } \\
\text { Millward and Lewis (2005) }\end{array}$ \\
\hline & & 0 & Difficulty in trusting motivated by regional culture, tradition* & None \\
\hline & & O & $\begin{array}{l}\text { Delay in delivering needed activities (e.g. putting off prototype } \\
\text { tests) - not related to availability of economic resources }\end{array}$ & None \\
\hline & & 0 & $\begin{array}{l}\text { To 'follow the crowd' attitude (join actions because others are } \\
\text { joining) }\end{array}$ & Sternberg $(2006,2012)$ \\
\hline & & 000 & Little understanding of product development/design & $\begin{array}{l}\text { Arquilla et al. (2015) } \\
\text { Filson and Lewis (2000) } \\
\text { Millward and Lewis (2005) }\end{array}$ \\
\hline & & & Not knowing product development and manufacturing costs & Filson and Lewis (2000) \\
\hline & \multirow{2}{*}{$\begin{array}{l}\text { Designers } \\
\text { Consultants }\end{array}$} & 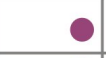 & Lack of experience, practice-based know-how & D'Ippolito (2014) \\
\hline & & 0 & $\begin{array}{l}\text { Lack of ability to communicate design knowledge to company } \\
\text { members }\end{array}$ & Brown (2009) \\
\hline & Policy makers & O & Lack of background in design management & $\begin{array}{l}\text { Cox (2005) } \\
\text { Maffei, Bianchini and Mortati (2014) }\end{array}$ \\
\hline
\end{tabular}

R Respondents

Beneficiaries

Designers and consultants

Policy makers
*Although there are studies emphasising the role of trust in some innovation ecosystems, research pointing out the lack of trust (motivated by regional culture) as an obstacle to design innovation was not found.

The difficulty in trusting and the delay in delivering required activities that would be carried out by the company in order to accomplish a design process phase were pointed out by respondents and identified as new barriers. The difficulty in trusting means that projects beneficiaries show reluctance to engage with consultants or to contribute to them mainly at first attempts of the project when they do not meet each other before. The delay in deliveries impacts design implementation and results (e.g. when tests cannot be carried out, problems are identified later, impacting time to market, and adding design activities to correct them).

Most barriers at the actors level were recognised by interviewees that collaborate with each other, having face-to-face contact throughout projects. 
Table 4 Barriers to design-driven innovation at the organisational level

\begin{tabular}{|c|c|c|c|c|}
\hline \multicolumn{2}{|c|}{ Level } & $R$ & Barrier & Prior research \\
\hline \multirow{18}{*}{ 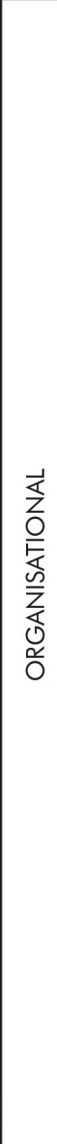 } & \multirow[t]{5}{*}{ Structure } & 00 & Limited resources & $\begin{array}{l}\text { Acklin (2013) } \\
\text { Larsen and Lewis (2007) }\end{array}$ \\
\hline & & 00 & $\begin{array}{l}\text { Limited in-house capabilities for conducting innovation } \\
\text { processes }\end{array}$ & $\begin{array}{l}\text { Acklin (2013) } \\
\text { Bruce, Cooper and Vazquez (1999) } \\
\text { Cox (2005) } \\
\text { Filson and Lewis (2000) }\end{array}$ \\
\hline & & 00 & Underdeveloped education and training & Larsen and Lewis (2007) \\
\hline & & & Lack of management skills & $\begin{array}{l}\text { Larsen and Lewis (2007) } \\
\text { Altenburg and Meyer-Stamer (1999) }\end{array}$ \\
\hline & & & Lack of manufacturing skills & Larsen and Lewis (2007) \\
\hline & \multirow[t]{7}{*}{ Culture } & & Use design support to address immediate needs during a crisis & Cawood (1997) \\
\hline & & & Cost-driven approach & Millward and Lewis (2005) \\
\hline & & 이 & Lack of top management support & $\begin{array}{l}\text { Cawood (1997) } \\
\text { Filson and Lewis (2000) } \\
\text { Larsen and Lewis (2007) } \\
\text { Schneider et al. (2015) }\end{array}$ \\
\hline & & & Lack of long-term strategy vision & $\begin{array}{l}\text { Cawood (1997) } \\
\text { Filson and Lewis (2000) }\end{array}$ \\
\hline & & & Weak external contacts & $\begin{array}{l}\text { Srinivasan, Lilian, and Rangaswamy (2002) } \\
\text { cited in Massa and Testa (2008) }\end{array}$ \\
\hline & & & Influence of a dominant owner/manager & $\begin{array}{l}\text { Bruce et al. (1999) } \\
\text { Millward and Lewis (2005) }\end{array}$ \\
\hline & & - & Lack of trust to build up partnerships & Larsen and Lewis (2007) \\
\hline & \multirow{6}{*}{$\begin{array}{l}\text { Design } \\
\text { process }\end{array}$} & & No clear new product development / design strategy & Filson and Lewis (2000) \\
\hline & & & Lack of competitors and suppliers knowledge & \multirow[t]{5}{*}{ Larsen and Lewis (2007) } \\
\hline & & & Domestic market orientation & \\
\hline & & & Lack of market launch plan and resource with stage gates & \\
\hline & & & Lack of early superior/differentiated product definition & \\
\hline & & & Lack of customers / users orientation & \\
\hline
\end{tabular}

R Respondents

Beneficiaries

Designers and consultants

Policy makers

Few organisational barriers were cited by participants during the interview. Policy makers identify the lack of economic resources and the lack of trust among entrepreneurs, this second one hinders collaboration among them. Designers and beneficiary recognise the need to have in-house capabilities, education and training. The lack of top management (generally the owner in MSMEs) support to collaborate towards design support projects is pointed out by a designer.

The barriers quoted by respondents can be understood as the ones that they perceive as having a clear impact on design introduction through design support initiatives.

Even though the other barriers have an important influence on the introduction of design into MSMEs, they were not spontaneously remembered. A possible reason for this can be the usual focus of projects that do not include a prior design audit or a strategic assessment before defining design support strategies and projects goals. Hence, generally, designers and consultants have the role of developing and implementing specific new products and communication elements that were previously established in the design support programme or project by policy makers. 
Table 5 Barriers to design-driven innovation at the ecosystem level

\begin{tabular}{|c|c|c|c|c|}
\hline \multicolumn{2}{|c|}{ Level } & $\mathrm{R}$ & Barrier & Prior research \\
\hline \multirow{20}{*}{ 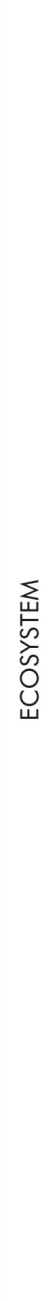 } & \multirow[t]{6}{*}{ Industry } & 0 & Lack of cooperation between businesses ${ }^{* *}$ & None \\
\hline & & 0 & Illegality in the market (non certified products/firms) & None \\
\hline & & & Difficulty in finding appropriate support with respect to design & $\begin{array}{l}\text { Arquilla et al. (2015) } \\
\text { Cox (2005) }\end{array}$ \\
\hline & & & Imitation strategy context & Altenburg and Meyer-Stamer (1999) \\
\hline & & & Inward focused (dedicated to domestic market and local content) & $\begin{array}{l}\text { Araúio (2016) } \\
\text { Arnold (2016) }\end{array}$ \\
\hline & & & Few design firms considering the size of the national population & CBD, Apex-Brasil, MDIC (2014) \\
\hline & \multirow[t]{6}{*}{ Policy } & 0 & Bureaucracy limitations to select/contract consultants & None \\
\hline & & & Bureaucracies related to intellectual property procedures & $\begin{array}{l}\text { Larsen and Lewis (2007) } \\
\text { Massa and Testa (2008) }\end{array}$ \\
\hline & & 00 & Bureaucracies related to local authorities / regulatory issues & $\begin{array}{l}\text { Acklin (2013) } \\
\text { Cox (2005) }\end{array}$ \\
\hline & & 0 & $\begin{array}{l}\text { No clear strategy to attend to a businesses / design cluster } \\
\text { demand / need - HOW }\end{array}$ & Maffei, Bianchini and Mortati (2014) \\
\hline & & & Fragmented design innovation ecosystem & $\begin{array}{l}\text { Maffei, Bianchini and Mortati (2014) } \\
\text { Raulik-Murphy and Cawood (2009) }\end{array}$ \\
\hline & & O & One shot projects without follow-ups or long run strategies & $\begin{array}{l}\text { Mazzucato and Penna, (2015) } \\
\text { Raulik-Murphy, Cawood, Larsen and Lewis } \\
\text { (2009) }\end{array}$ \\
\hline & \multirow[t]{5}{*}{ Economy } & & Lack of credit availability & $\begin{array}{l}\text { Bell (2015) } \\
\text { Larsen and Lewis (2007) }\end{array}$ \\
\hline & & & Low exposure to foreign competition & $\begin{array}{l}\text { Araújo (2016) } \\
\text { Arnold (2016) }\end{array}$ \\
\hline & & & Industry heavily protected from international competition & $\begin{array}{l}\text { Araújo (2016) } \\
\text { Arnold (2016) }\end{array}$ \\
\hline & & & Unemployment & Altenburg and Meyer-Stamer (1999) \\
\hline & & & Few jobs in the design sector & CBD, Apex-Brasil, MDIC (2014) \\
\hline & \multirow[t]{3}{*}{ Education } & & Lack of skills, education to move towards innovation & $\begin{array}{l}\text { Altenburg and Meyer-Stamer (1999) } \\
\text { OECD (2014) }\end{array}$ \\
\hline & & & Few design graduates considering the national population size & CBD, Apex-Brasil, MDIC (2014) \\
\hline & & ( & Lack of end-users education to recognise design value & Swann (2010) \\
\hline
\end{tabular}

R Respondents

Beneficiaries

Designers and consultants

Policy makers
**Although the cooperation between businesses is a recognised driver (Cantù, 2013; Rullani, 2011; Symbola \& Unioncamere, 2016; Wenger, 2011), research pointing out the lack of cooperation as an obstacle to design innovation in the context of design support was not found.

The lack of cooperation between businesses and the illegality in the market were the new barriers recognised in the industry.

The lack of cooperation is when beneficiaries see the other beneficiaries as competitors that can 'steal their ideas or know-how' more than allies to achieve a goal. In the case of the studied design support projects, the cooperation is not characterized by interdependence and mutual influence 5 among firms in the same industry, since access to external resources such as a design consultancy is assured when the businesses formally join the project, which means that one company will access the competences proposed in the project regardless of other companies' attitudes, conditions and commitment. This cannot be seen as a network because the motivation to join other businesses is mainly based on sharing the investment costs and on the voucher scheme to exploit a resource, not requiring trust (among businesses), commitment or skills from beneficiaries.

Thus, the kind of collaboration identified means 'to help one another' or to learn in a collective process without prior relationships fostered by a bottom-up approach to business needs and to strategies formulation (to exploit resources). In this sense, the way the design support projects are

\footnotetext{
5 i.e. Cantù (2013) explains that these two factors are present in different types of network, including interpersonal ones.
} 
generally designed (top-down process) as well as how businesses join projects do not favour cooperation.

The illegality in the market (shadow economy products) represents the fact that some producers sell their products without quality requirements and compulsory certifications in the market as if they were made in a region where they were not, communicating this misleading information to customers through package and brand. These products are generally cheaper than original and quality-certified products, thereby affecting the competition in the retail market as the customer is not able to distinguish them.

The top-down approach to policy-making leads to the identification of another new barrier: the extensive regulations to contract consultants makes the process slower compared to hiring the designer or consultant in the market situation. Furthermore, the consultant has to fit in several requirements that are not related to their design background, reputation or competence to attain the projects' goals. Another issue is that some of these regulations' requirements counteract the idea of the design policy role (including design support) to balance or stimulate design supply and demand, making the conditions of private studios not suitable to hire them regardless of their competences and reputation.

Most ecosystem barriers were not cited by respondents. Some possible reasons can be that people get used to the national conditions just adapting to them, seeing things within the national boundaries context, another can be the top-down policy approach that discourages taking actions and trying to change a system that lacks meritocracy. The lack of education and skills towards innovation can also lead to hide the weaknesses at the ecosystem level (how can one recognise something in which one has no background or experience?). An additional evidence is the time required to formally recognise by law the designer profession in Brazil, an attempt that comes from 1980 (CBD, Apex-Brasil, MDIC, 2014) and is still being carried out with limited content being discussed regarding the global expansion and importance of design at organisational and national level.

\section{Implications and recommendations on design support}

All in all, design is not a priority throughout the policy programmes and projects. It is used in practice to achieve other priorities related to, for example, regulations, adequacies to technology and market requirements characterized by short-term strategies, immediate perspectives towards which benefits can be achieved, being more 'pushed' interventions than 'pulled' ones.

Hence, design as a connector, a functional integrator; an enabler of product-service systems (PSS) that fosters innovation to users; as a strategic driver; a way to boost economic growth; to envision futures, collaborating and co-creating them together with citizens, users or beneficiaries of policies, is not observed in project practices, policy priorities and approaches.

In addition, looking at the design support and policy frameworks, and at most research and supportive institutions that relate to design, leads to the interpretation that design is seen as an addition, being usually included in other policy priority such as technology or quality requirements to attain compulsory regulations. There are exceptions regarding this design understanding considering the aforementioned diversity, heterogeneity of design in Brazil. However, analysing the picture of the Brazilian Design Innovation Ecosystem and how it works we may state that generally the potential of design has a very limited understanding. This is evidenced by organisational, institutional and political practices as well as by current Brazilian design management research (e.g. CBD, Apex-Brasil, MDIC, 2014; Murphy, \& Raulik Murphy, 2015) that also evidences the lack of data at national level, including public investment in design (CBD, Apex-Brasil, MDIC, 2014).

The difficulty in identifying public investment can be due to the inclusion of design as additional asset in other branches of policies programmes or to the lack of specific policies, institutions and agencies concerned with design. Furthermore, the fragmentation of the design innovation 
ecosystem and the way annual accountability reports were done do not facilitate (a) the communication to a general public (citizens) and (b) to distinguish which part was specifically destined to design as well as measurable evidence of benefits directly related to the design interventions.

The suggested recommendations in order to start improving design support in Brazil are mainly related to the policy maker role, considering the current top-down approach to design support programmes. They are:

- To increase designers, consultants and beneficiaries participation in the policy-making process, so they can take part in the definitions of projects' goals and strategies. This kind of earlier beneficiaries' involvement tends to make them strongly committed to the project once they participate in its decisions. Designers and other experts can support prior assessments to design appropriate policy projects according to beneficiaries needs and conditions. The collaboration with experts in earlier phases can avoid misleading decisions regarding the lack of background in design;

- To set clear goals and strategy during the earlier collaborative phase. For instance, what is to be achieved, the competences required, how the programme/project will be carried out, who will be in charge of what and how, communicating this information to all key stakeholders;

- To revise best practices in their field across the world, several aspects related to MSMEs conditions to absorb design-driven innovation through design support programmes are not particular of a context but found in other situations too;

- To look for tools that can support design programmes and projects as well as experts' collaboration in order to strengthen their design capabilities towards future projects;

- To be updated and informed about the regional, national and global content and data related to design support programmes/projects as well as design in the world and in Brazil (collecting also current and comparable data in time), building on reasoning that evidences the impact on the Brazilian society and economy in order to negotiate required changes (e.g. to decrease bureaucracy and better consider meritocracy) to better accomplish their role in the supply and demand of design in Brazil as well as to define budget destinations;

- To move the focus of the work from inside the institution (e.g. fulfilling demanding forms and reports) to outside, including visits to beneficiaries with specific purpose of understanding their needs and conditions, listening to their expectations and what they need from the institution;

- To be immersed in the design world. To cultivate an environment that includes the design industry professionals as well as beneficiaries, promoting when possible events and meetings where people can have the opportunity to meet each other, share knowledge, propose solutions to common problems or discuss businesses' topics that interest both. To be present in design sector events and fairs (not just related to the institution).

\section{Challenges of introducing design-driven innovation: What is next?}

The next challenges come from the preferred scenario where critical variables were identified in each level:

1. the design support programmes/projects have an important social and economic impact;

2. the processes of policy-making are participatory;

3. the programmes/projects are evaluated ${ }^{6}$ and monitored regarding short and long term benefits/impacts;

\footnotetext{
${ }^{6}$ Evaluation framework has been discussed in Europe (Maffei, Arquilla, Mortati, Villari, Evans, Chisholm, \& Londoni, 2014) and the assessment of design has been matter of discussion at micro (Fonseca Braga, 2016)
} 
4. the organisations are international market focused, human-centred and future-oriented;

5. the actors are design aware and build on appropriate education and skills to lead designinnovation.

In order to propose strategies to achieve this scenario, the How Might We (HMW) questions (Ideo.org, n.d.) are proposed to be answered in collaboration with key stakeholders' representatives through a co-creation workshop using design thinking methods. The HMW questions elaborated are:

1. the design support programmes/projects have an important social and economic impact;

- How might design support programmes/projects propose goals that have an important social and economic impact?

- How might we communicate design support impacts to the general public and to potential partners?

2. the processes of policy-making are participatory;

- How might policy makers elaborate new ways of crafting design support programmes/projects in collaboration with experts and beneficiaries?

3. the programmes/projects are evaluated and monitored regarding short and long term benefits/impacts;

- How might we evaluate short and long-run benefits/impacts of design support programmes/projects?

- How might we monitor short and long-run benefits/impacts of design support programmes/projects?

4. the organisations are international market focused, human-centred and future-oriented

- How might design support programmes/projects prepare companies/beneficiaries to become internationally competitive?

- How might design support programmes/projects make the firms be dedicated to their users' needs?

- How might design support programmes/projects make the firms be future-oriented?

5. the actors are design aware and build on appropriate education and skills to lead designinnovation;

- How might we make policy makers and beneficiaries aware of design?

- How might we improve policy makers and beneficiaries conditions of education and skills towards design-driven innovation?

\section{Limitations and future research}

Research in the design policy field is acknowledged as a new phenomenon despite the long tradition of design policy practice, remaining the lack of conceptual and theoretical foundations (Hobday, Boddington and Grantham, 2012; Raulik-Murphy, 2010). Moreover, the diversity of design policy programmes, the lack of common terminology, definitions, comparable data and indicators across countries, policies and projects also evidence this aspect (Raulik-Murphy, 2010). In addition, there is the lack of studies and data related to design in the Brazilian context (CBD, Apex-Brasil, MDIC, 2014). The literature used to support the cases analysis is fragmented coming from several fields as a consequence of the holistic view required to inquiry the issues proposed.

Design support programmes and projects per se do not assure the design acknowledgement and potential design use within companies and countries. The need for diverse interventions that can be

and macro Schneider et al., 2015) levels. We need to consider local conditions and actors' perspectives, understanding current frameworks in order to analyse and generate alternatives for the Brazilian case. 
combined with design support is recognised (Cox, 2005; Raulik-Murphy, 2010; Swann, 2010). Hence, this is one of this research limitations. This study looks at design support and its recommendations focus on that.

The next steps of this research aim at (1) pointing out the drivers to introducing design-driven innovation that have also been analysed but were not discussed in this paper, and (2) generating answers to the challenges in collaboration with key stakeholders through a co-creation workshop using design thinking methods. It can be seen as an experimentation for a bottom-up approach to start crafting future design support interventions, and their possible strategies.

A further step towards the implementation of collaborative strategies that can be adopted by policy makers is to apply a survey in order to validate and improve strategies considering a representative population.

Acknowledgements: We thank the National Council for Scientific and Technological Development (CNPq, Brazil) for funding this research and Politecnico di Milano, especially the Design Strategy unit and the Creative Industries Lab (Cl-lab), where this study has been carried out. We are also grateful to our external partners, Viviane dos Guimarães Alvim Nunes and Gisele Raulik Murphy, for their comments and conversations on the topics discussed, and to Silvia Xavier for her reading of and comments on this paper.

\section{References}

Acklin, C. (2013). Design Management Absorption Model - A framework to describe and measure the absorption process of design knowledge by SMEs with little or no prior design experience. Creativity and Innovation management, 22(2), 147-160.

Airaksinen, A., Luomaranta, H., Alajääskö, P., \& Roodhuijzen, A. (2015). Statistics on small and medium-sized enterprises. Dependent and independent SMEs and large enterprises. Retrieved November 21, 2016, from http://ec.europa.eu/eurostat/statistics-explained/index.php/Statistics_on_small_and_mediumsized_enterprises.

Altenburg, T., Meyer-Stamer, J. (1999). How to Promote Clusters: Policy Experiences from Latin America. World Development. doi: 10.1016/S0305-750X(99)00081-9.

Araújo, S. (2016). Untying the knots strangling Brazil's competitiveness. OECD ECOSCOPE. Retrieved from: https://oecdecoscope.wordpress.com/2016/05/20/untying-the-knots-strangling-brazils-competitiveness/

Arquilla, V., Maffei, S., Mortati, M., Villari, B. (2015). Assessing European Design Policy: Towards an Evaluation Culture. In L. Collina, L. Galluzzo, A. Meroni (Eds.), Proceedings of the Culumus Conference: The Virtuous Circle (pp. 915-926). Milan: McGraw-Hill Education Italy. Retrieved May 30, 2016, from http://cumulusmilan2015.org/proceedings/articles/abs-068-Assessing/

Arnold, J. (2016). Brazil: A tale of two industries or how openness to trade matters. OECD ECOSCOPE. Retrieved from: https://oecdecoscope.wordpress.com/2016/03/22/brazil-a-tale-of-two-industries-or-how-opennessto-trade-matters/

Bell, S. (2015). Small and Medium Enterprises (SMEs) Finance. Retrieved November 21, 2016, from: http://www.worldbank.org/en/topic/financialsector/brief/smes-finance

Borges, A. (2011). Design + artesanato: o caminho brasileiro [Design + crafts: the Brazilian way]. São Paulo, Brazil: Terceiro Nome.

Borges, A. (2009). Design. In: Cultural Mapping Brazil 2009, pp. 52-85. Dutch Culture Centre for International Cooperation. Retrieved from: https://brazil.dutchculture.nl/sites/default/files/Cultural_Mapping_Brazil_2009_by_DutchCulture.pdf

Bradesco. (2017). Indústria de Móveis [Furniture Industry]. Departamento de Pesquisas e Estudos Econômicos. Economia em dia, Osasco. Retrieved June, 2017, from: https://goo.gl/pvm9Dr.

Brown, T. (2009). Change by design: how design thinking transforms organizations and inspires innovation. New York, NY: HarperCollins Publishers.

Bruce, M.; Cooper, R.; Vazquez, D. (1999). Effective design management for small businesses. Design Studies 20, 297-315.

Caloête, E. Q. M., Westin, D. G. (Coord.). (2014). Serviço Brasileiro de Apoio às Micro e Pequenas Empresas (SEBRAE) - Design no Brasil: relatório 2014 do setor de design [The Brazilian Micro and Small Businesses Support Service - Design in Brazil: report 2014]. Brasília, Brazil: Sebrae. Retrieved from: 
https://www.sebrae.com.br/sites/PortalSebrae/artigos/o-design-no-brasil-relatorio2014,6d818242d5e67410VgnVCM1000003b74010aRCRD

Cantù, C. (2013). Innovazione e prossimità relazionale. I/ contesto dei parchi tecnologici [Innovation and relational proximity. The context of technology parks]. Milan, Italy: Franco Angeli.

Cawood, G. (1997). Design Innovation and Culture in SMEs. Design Management Journal, 8(4), 66-70.

CBD, Apex-Brasil, MDIC. (2014). Diagnostic Review of Design in Brazil. Retrieved from: http://www.cbd.org.br/downloads/

CNI.(n.d.a). SENAI [the National Service of Industrial Training (SENAI)]. Retrieved November 3, 2017, from: http://www.portaldaindustria.com.br/senai/en/about/senai/

CNI. (n.d.b). Structure. Retrieved November 3, 2017, from: http://www.portaldaindustria.com.br/senai/en/about/structure/

CNI. (n.d.c). Variáveis e fontes [Variables and sources]. Retrieved November 3, 2017, from: http://perfilestados.portaldaindustria.com.br/variaveis

Cox, G. (2005). Cox Review of Creativity in Business: building on the UK's strengths. Retrieved June 3, 2016, from http://webarchive.nationalarchives.gov.uk/

Danish Design Centre. (2003) The Economic Effects of Design. Copenhagen: National Agency for Enterprise and Housing. Retrieved from: http://www.seeplatform.eu/images/the_economic_effects_of_designn.pdf

Design Council. (2015). The Design Economy: The value of design to the UK economy. Retrieved July 14, 2017, from: http://www.designcouncil.org.uk/resources/report/design-economy-report

Design Council. (2007). The Value of Design: Factfinder report. Retrieved from: https://www.designcouncil.org.uk/sites/default/files/asset/document/TheValueOfDesignFactfinder_Desig n_Council.pdf.

D'Ippolito, B. (2014). The importance of design for firms' competitiveness: A review of the literature. Technovation, 34, 716-730. doi: 10.1016/j.technovation.2014.01.007

ECLAC (2015). The European Union and Latin American and the Caribbean in the new economic and social context. Retrieved June 16, 2015, from http://repositorio.cepal.org/bitstream/handle/11362/38230/S1500330_en.pdf?sequence=1.

Eisenhardt, Kathleen M. (1989). Building Theories from Case Study Research. Academy of Management. The Academy of Management Review, 14 (4): 532-550.

European Commission (2015a). AL-INVEST 5.0: Inclusive Growth for Social Cohesion in Latin America Guidelines for grant applicants. Retrieved June 7, 2015, from

https://webgate.ec.europa.eu/europeaid/online-

services/index.cfm?ADSSChck=1435233844256\&do=publi.detPUB\&searchtype=AS\&orderbyad=Desc\&Pgm $=7573839$ \& nbPubliList $=15$ \&zgeo=35380 \&page $=1$ \&debpub=\&aoref=150066\&orderby=upd \&userlanguage $=$ en.

European Commission. (2016). Design for innovation. Retrieved November 14, 2016, from http://ec.europa.eu/growth/industry/innovation/policy/design/index_en.htm

European Commission. (2015b). User guide to the SME definition. Luxembourg: Publications Office of the European Union. Retrieved February 12, 2016, from http://ec.europa.eu/growth/toolsdatabases/newsroom/cf/itemdetail.cfm?item_id=8274\&lang=en

Filson, A., Lewis, A. (2000). Barriers between Design and Business Strategy. Design Management Journal, 11 (4), 48-52.

Fonseca Braga, M. (2017). The choice of design. From businesses' conditions to businesses' attitudes. The Design Journal, 20:sup 1, S635-S646. doi: 10.1080/14606925.2017.1353011

Fonseca Braga, M. (2016). The value of design: an issue of vision, creativity and interpretation. In P. Lloyd \& E. Bohemia (Eds.), DRS 2016 Conference Proceedings (pp. 1865-1881). London, UK: Design Research Society.

Galinari, R., Teixeira Junior, J. R., \& Morgado, R. R. (2013). A competitividade da indústria de móveis do Brasil: situação atual e perspectivas [The competitiveness of the Brazilian furniture industry: current situation and perspectives]. BNDES Setorial, 37, 227-272. Retrieved August 4, 2015, from http://www.bndes.gov.br/SiteBNDES/export/sites/default/bndes_pt/Galerias/Arquivos/conhecimento/bns et/set3706.pdf

Glaser, B. G., Strauss, L. A. (1967) The discovery of grounded theory: Strategies for qualitative research. Chicago: Aldine Publishing Co.

Guedes, S. (2014). Confecções apostam no mercado varejista para aumentar a competitividade [Lingerie manufacturers bet on the retail market to increase competitiveness]. Retrieved from: http://www.agenciasebrae.com.br/sites/asn/uf/NA/confeccoes-apostam-no-mercado-varejista-paraaumentar-a-competitividade,37c397f2be388410VgnVCM2000003c74010aRCRD 
Heskett, J. (2009). Creating Economic Value by Design. International Journal of Design, 3(1), 71-84.

Hobday, M.; Boddington, A. ; Grantham, A. (2012). Policies for design and policies for innovation: Contrasting perspectives and remaining challenges. Technovation, 32, 272-281.

doi:10.1016/j.technovation.2011.12.002

Ideo.org. (n.d.). How Might We. Design kit. Retrieved from: http://www.designkit.org/methods/3

INEP. (2017). Sinopse Estatística da Educação Superior 2016 [Synopsis of Higher Education 2016]. Retrieved from: http://inep.gov.br/web/guest/sinopses-estatisticas-da-educacao-superior

Kootstra, G. L. (2009) Design Management Europe Survey 2009. The incorporation of design management in today's business practices: An analysis of design management practices in Europe. Rotterdam, The Netherlands: Centre for Brand, Reputation and Design Management, INHOLLAND University of Applied Sciences. Retrieved from: http://www.bcd.es/site/unitFiles/2585/DME_Survey09darrera\%20versi\%C3\%B3.pdf

Kraichete, D. (2015). Mapping Brazil - Design. DutchCulture centre for international cooperation. Retrieved from: https://brazil.dutchculture.nl/en/mapping/mapping-brazil-design-0

Larsen, P., Lewis, A. (2007). How Award-Winning SMEs Manage the Barriers to Innovation. Creativity and Innovation Management, 16(2), 142-151. doi:10.1111/j.1467-8691.2007.00428.x

Madeuf, B., \& Estimé, MF. (2000). Compendium on International and Regional Bodies: Activities and Initiatives Related to Small and Medium-Sized Enterprises (SMEs). Retrieved September 20, 2016, from https://www.oecd.org/cfe/smes/2090691.pdf

Maffei, S., Arquilla, V., Mortati, M., Villari, B, Evans, M., Chisholm, J., \& Londoni, P. (2014). Design in European Policy (DeEP) final publication. Retrieved March 3, 2016, from: http://www.deepinitiative.eu/wpcontent/uploads/2012/12/DEEP_FINAL-PUBLICATION.pdf

Maffei, S.; Bianchini, M.; Mortati, M. (2014) Design 2020. Le sfide della trasformazione del sistema design Lombardo [Design 2020. The challenges of transforming the Lombard design system]. Regione Lombardia, Direzione Generale Commercio, Turismo e Terziario, Milano, Italia: Libraccio Editore. Retrieved May 31, 2016, from http://www.designpolicy.eu/wpcontent/uploads/2016/04/RegioneLombardia_DESIGN2020_Documento-Finale.pdf

Maffei, S., Mortati, M., Villari, B. (2014). Making/Design Policies Together. In: M. Mortati, L. Cruickshank, S. Maffei, \& M. Evans (Eds.), 10th European Academy of Design Conference - Crafting the Future (pp. 1-14). Gothenburg, Sweden: European Academy of Design. Retrieved from: http://www.trippus.se/eventus/userfiles/67172.pdf

Marzano, Francelle. (June 13, 2015). Queijo de Minas é premiado em competição internacional realizada na França [Cheese from Minas is awarded in international competition held in France]. Retrieved from: http://www.em.com.br/app/noticia/economia/2015/06/13/internas_economia,657775/queijo-de-minase-premiado-na-franca.shtml

Massa, S.; Testa, S. (2008). Innovation and SMEs: Misaligned perspectives and goals among entrepreneurs, academics, and policy makers. Technovation, 28, 393-407. doi: 10.1016/j.technovation.2008.01.002

Mazzucato, M., Penna, C. (2015). The Brazilian Innovation System: A Mission-Oriented Policy Proposal. Avaliação de Programas em CT\&I. Apoio ao Programa Nacional de Ciência (Plataformas de conhecimento). Brasília, DF: Centro de Gestão e Estudos Estratégicos.

Micheli, P. (2014). Leading Business by Design. Why and how business leaders invest in design. Design Council and Warwick Business School. Retrieved June 3, 2016, from http://www.designcouncil.org.uk/sites/default/files/asset/document/dc_lbbd_report_08.11.13_FA_LORES .pdf

Millward, H., Lewis, A. (2005). Barriers to successful new product development within small manufacturing companies. Journal of Small Business and Enterprise Development, 12 (3), 379-394. doi: 10.1108/14626000510612295

Moraes, D. (2006). Análise do design brasileiro: entre mimese e mestiçagem [Analysis of the Brazilian design between mimesis and miscegenation]. São Paulo, Brazil: Blucher.

Moraes Junior, D. (2002). Il rapporto locale-globale, nuova sfida ed opportunità progettuale: il Brasile come caso locale [The local-global relationship, the new design challenge and opportunity: Brazil as the local case]. PhD thesis. Milan, Italy: Politecnico di Milano.

Mortati, M.; Cruickshank, L. (2011). Design and SMEs: the trigger of creative ecosystems. In: Proceedings of the Conference DPPI11, Milan, Italy. DOI: 10.1145/2347504.2347550

Moultrie, J. \& Livesey, T.F. (2009). International Design Scoreboard - Initial indicators of international design capabilities. Great Britain: IfM and University of Cambridge. Retrieved May 30, 2016, from https://www.designcouncil.org.uk/sites/default/files/asset/document/InternationalDesignScoreboard.pdf 
Murphy, D., \& Raulik Murphy, G. (2015). The Design Innovation Performance of Paraná Businesses. Centro Brasil Design (CBD) and Duco - Driving Design Strategies. Retrieved from:

http://www.cbd.org.br/downloads/

Nunes, V. G.A. (2014). What Does Design \& Innovation Mean for MSEs? A case study of eight Brazilian furniture firms. in: E. Bohemia, A. Rieple, J. Liedtka, R. Cooper, eds., Proceedings of the 19th DMI Academic Design Management Conference: Design Management in an Era of Disruption. Chapter 1, pp 95-108.

OECD. (2013). Economic Surveys: Brazil 2013. Paris: OECD, 2013. Retrieved June 16, 2015, from: https://goo.gl/iY4r5y

OECD (2016). Financing SMEs and Entrepreneurs 2016: An Scoreboard. OECD Publishing, Paris, France. doi: 10.1787/fin_sme_ent-2016-en. Retrieved November 7, 2016, from http://www.keepeek.com/Digital-AssetManagement/oecd/industry-and-services/financing-smes-and-entrepreneurs-2016_fin_sme_ent-2016en\#.WC64m3fMw0o\#page3

OECD. (2014). Latin American Economic Outlook 2015: Education, Skills and Innovation for Development. OECD Publishing. doi:10.1787/leo-2015-en.

OECD (2006). The Financing Gap (Vol. 1): Theory and Evidence. Paris, France: OECD Publishing.

Rae, J. (2013). Design-Conscious Companies: What Is the Real Value of Design? Design Management Institute, 30-37. Retrieved October 26, 2015, from https://www.dmi.org/resource/resmgr/pdf_files/TheRealValueOfDesign.pdf

Rae, J. (2014). What Is the Real Value of Design? Design Management Institute and Motiv Strategies, 1-9. Retrieved October 26, 2015, from http://motivstrategies.com/work/what-is-the-real-value-of-design/

Raulik-Murphy, G. (2010). A Comparative Analysis of Strategies for Design Promotion in Different National Contexts. PhD thesis. Cardiff, UK: University of Wales.

Raulik-Murphy, G., Cawood, G., Larsen, P., \& Lewis, A. (2009). A comparative analysis of strategies for design in Finland and Brazil. In: Undisciplined! Design Research Society Conference 2008 (pp. 201/1-201/16). Sheffield, UK: Design Research Society.

Raulik-Murphy, G., Cawood, G. (2009). 'National Design Systems' - a tool for policy making. Research Seminar: Creative industries and regional policies: making place and giving space. Birmingham: University of Birmingham. Retrieved May 27, 2016, from http://www.seeplatform.eu/images/National\%20Design\%20Systems\%20-\%20a\%20tool\%20for\%20policymaking.pdf

Rullani, E. (2011). L'economia della conoscenza nel capitalismo delle reti [The knowledge economy in the capitalism of networks]. Sinergie Italian Journal of Management, [S.I.], 67-90. Retrieved from: http://sinergiejournal.eu/index.php/sinergie/article/view/s76.2008.07

Schneider, J., Gibet, S., Colomb, A., Orazem, V., Loesch, SL., Kasparyan, C., Salminen, J. (2015). Supporting design driven innovation: a review of selected programmes. Regions supporting Entrepreneurs and Designers to Innovate (REDI). Retrieved May 24, 2016, from http://www.apci.asso.fr/magazine/categorie/activites/rapport-redi-soutenir-l-innovation-par-le-designanalyse-de-quelques-programmes

SEBRAE, DIEESE. (2015). Anuário do trabalho na micro e pequena empresa: 2014 [Annual review of jobs in micro and small enterprises: 2014]. Retrieved from:

https://m.sebrae.com.br/Sebrae/Portal\%20Sebrae/Anexos/Anuario-do\%20trabalho-na\%20micro-epequena\%20empresa-2014.pdf

SEBRAE. (2014). Participação das Micro e Pequenas Empresas na Economia Brasileira [Participation of Micro and Small Businesses in the Brazilian Economy]. Retrieved from:

https://m.sebrae.com.br/Sebrae/Portal\%20Sebrae/Estudos\%20e\%20Pesquisas/Participacao\%20das\%20mi cro\%20e\%20pequenas\%20empresas.pdf

SEBRAE. (n.d.a). Quem são os pequenos negócios? [Who are the small businesses?] Retrieved Nov. 3, 2017, from: http://www.sebrae.com.br/sites/PortalSebrae/estudos_pesquisas/quem-sao-os-pequenosnegociosdestaque5,7f4613074c0a3410VgnVCM1000003b74010aRCRD

SEBRAE. (n.d.b). 700 Service Centers throughout Brazil. Retrieved Nov. 3, 2017, from: http://www.sebrae.com.br/sites/PortalSebrae/canais_adicionais/sebrae_english

Silveira da Rosa, S. E., Correa, A. R., Lemos, M. L. F., \& Barroso, D. V. (2007). O setor de móveis na atualidade: uma análise preliminar [The furniture industry today: a preliminary analysis]. BNDES Setorial, 25, 65-106. Retrieved September 15, 2015, from http://www.bndes.gov.br/SiteBNDES/export/sites/default/bndes_pt/Galerias/Arquivos/conhecimento/bns et/set2503.pdf

Simon, H. A. (1996). The Sciences of the Artificial, 3rd edition. Cambridge, Massachusetts: MIT Press. 
Stake, R. E. (2000) Case Studies. In.: DENZIN, N. K., \& LINCOLN, Y. S. (eds.). Handbook of Qualitative Research. 2nd ed. Thousand Oaks, California: Sage Publications. p. 435-454.

Sternberg, R. J. (2012). The Assessment of Creativity: An Investment-Based Approach. Creativity Research Journal, 24(1), 3-12. DOI: 10.1080/10400419.2012.652925

Sternberg, R. J. (2006). The Nature of Creativity. Creativity Research Journal, 18(1), 87-98. DOI: 10.1207/s15326934crj1801_10

Swann, P. G. M. (2010). The economic rationale for a national design policy. Retrieved April 18, 2016, from https://www.gov.uk/government/uploads/system/uploads/attachment_data/file/32096/10-1112-bisoccasional-paper-02.pdf

Symbola, Unioncamere (2016). Coesione è Competizione: Nuove geografie della produzione del valore in Italia. [Cohesion is Competition: New Geographies of Value Production in Italy] Retrieved January 9, 2017, from http://www.symbola.net/html/article/coesioneecompetizione

Thomson, M., Koskinen, T. (Eds.) (2012). Design for growth and prosperity. Report and Recommendations of the European Design Leadership Board. Retrieved May 3, 2016, from www.icsid.org Verganti, R. (2003). Design as brokering of languages: Innovation strategies in Italian firms. Design Management Journal, 34-42.

Verganti, R. (2003). Design as brokering of languages: Innovation strategies in Italian firms. Design Management Journal, 34-42.

Verganti, R. (2008). Design, meanings and radical innovation: A meta-model and a research agenda. The Journal of Product Innovation Management, 25, 436-456.

Wenger, E. (2011). Communities of practice: A brief introduction. Retrieved May 10, 2017, from https://scholarsbank.uoregon.edu/xmlui/handle/1794/11736?show=full

Whicher, A.; Swiatek, P.; \& Cawood, G. (2015). Design Policy Monitor 2015: Reviewing Innovation and Design Policies across Europe. Retrieved April 18, 2016, from http://www.seeplatform.eu/docs/SEE\%20DPM\%202015\%20Jan.pdf

Whicher, A., \& Walters, A. (2014). Mapping Design for Innovation in Wales \& Scotland. Research report, Arts and Humanities Research Council (AHRC). Retrieved from: https://repository.cardiffmet.ac.uk/handle/10369/6561

Yin, R. K. (1994). Case Study Research: Design and Methods, 2. ed. London, UK: Sage Publications.

About the Authors:

Mariana Fonseca Braga is a designer with a master's degree in Industrial Engineering, and a background in design innovation management, product and service design. She is a PhD candidate in Design at Politecnico di Milano. Her research interests are: strategic design, design management and policies.

Francesco Zurlo is PhD in industrial design and Full Professor of Industrial Design at Politecnico di Milano, in the courses of Integrated Product Design and Management Engineering. He's Deputy Dean of the Design School and Head of the Course in Product Design (BA+MAs) among other positions held. He is author of numerous international publications about strategic design. 